\title{
Development of Monoclonal Antibodies against HIV-1 p24 Protein and Its Application in Colloidal Gold Immunochromatographic Assay for HIV-1 Detection
}

\author{
Yi Ma, ${ }^{1}$ Chao Ni, ${ }^{1}$ Emmanuel E. Dzakah, ${ }^{1}$ Haiying Wang, ${ }^{1}$ Keren Kang, ${ }^{2}$ Shixing Tang, \\ Jihua Wang, ${ }^{2}$ and Jufang Wang ${ }^{1}$ \\ ${ }^{1}$ School of Bioscience and Bioengineering, South China University of Technology, Guangzhou 510006, China \\ ${ }^{2}$ National Engineering Laboratory of Rapid Diagnostic Tests, Guangzhou Wondfo Biotech Co., Ltd., Guangzhou 510663, China
}

Correspondence should be addressed to Jufang Wang; jufwang@scut.edu.cn

Received 10 December 2015; Accepted 15 February 2016

Academic Editor: Basel Khraiwesh

Copyright (c) 2016 Yi Ma et al. This is an open access article distributed under the Creative Commons Attribution License, which permits unrestricted use, distribution, and reproduction in any medium, provided the original work is properly cited.

Human immunodeficiency virus type 1 (HIV-1) p24 protein is the most abundant viral protein of HIV-1. This protein is secreted in blood serum at high levels during the early stages of HIV-1 infection, making it a biomarker for early diagnosis. In this study, a colloidal gold immunochromatographic assay (GICA) was established for detecting p24 protein using mouse monoclonal antibodies (mAbs). The HIV-1 p24 protein was expressed in E. coli strain BL21 and the purified protein was used to immunize mice. Stable hybridoma cell lines secreting anti-p24 monoclonal antibodies were obtained after ELISA screening and subcloning by limiting dilution. 34 different capture and labeling $\mathrm{mAb}$ pairs were selected by a novel antibody-capture indirect sandwich ELISA and then applied in GICA to detect p24 protein. The GICA method has a limit of detection (LOD) of $25 \mathrm{pg} / \mathrm{mL}$ and could detect p24 protein in all 10 positive samples obtained from the National Reference of HIV-1 p24 antigen. Out of 153 negative samples tested, 3 false positives results were obtained. The overall specificity of this test was $98.03 \%$. The good sensitivity and specificity of this method make it a suitable alternative to provide a more convenient and efficient tool for early diagnosis of HIV infection.

\section{Introduction}

P24 protein is derived from the Gag protein of HIV-1 and plays an important role in viral core assembly and maturation [1, 2]. HIV-1 RNA, anti-HIV antibodies, and p24 antigen are viral markers which have been used as a target antigen for early detection of HIV-1 infection [3,4]. Over the past two decades, HIV immunoassays have gone through first-generation (using viral lysate for IgG antibody detection), second-generation (using recombinant antigens for IgG antibody detection), third-generation (IgM and IgG antibodies detection), and fourth-generation (antibody and p24 antigen detection) immunoassay. These test kits have helped to shorten the "window period" and provide an early diagnosis for suspected HIV infected samples as compared with the third-generation immunoassays.
Enzyme linked immunosorbent assay (ELISA) is the most commonly used immunoassay in the third- and fourthgeneration test kits for HIV diagnosis in China. The limit of detection (LOD) for p24 antigen ranges from $11 \mathrm{pg} / \mathrm{mL}$ to $70 \mathrm{pg} / \mathrm{mL}$ [5]. However, ELISA involves complicated procedures and requires long reaction time of at least 2 hours. GICA has therefore been recognized as a popular diagnostic tool for the detection of HIV antibody because of its userfriendly format and easy and rapid rate of obtaining results without the need for special equipment [6-8]. There is no comprehensive study on p24 antigen detection using GICA and thus, the development of HIV-p24 antigen GICA, which can be used simultaneously with the HIV antibody GICA for rapid HIV detection, is of great significance. In this work, $\mathrm{mAbs}$ were screened against recombinant $\mathrm{p} 24$ protein and its application in GICA for HIV-1 detection was explored. 


\section{Materials and Methods}

2.1. Strains, Plasmids, Enzymes, and Reagents. Competent E. coli cells DH5 $\alpha$ and BL21 (DE3) were purchased from TIANGEN Biotech (Beijing, China). Restriction endonucleases NdeI and XhoI, Premix LA Taq, and DNA Ligation Kit were purchased from TAKARA Biotechnology Co., Ltd. (Dalian, China). SP2/0-Ag14 myeloma cells and pET-28a plasmid were preserved in our lab. All chemicals used in this study were of analytical grade.

2.2. Samples Collection and Examination. The National Reference of HIV-1 p24 antigen containing 10 positive samples (P1 to P10) and 10 sensitivity samples (L1 to L10) was purchased from the National Institute for the Control of Pharmaceutical and Biological Products (Beijing, China). These sensitivity samples were p 24 protein (WHO standards) from the National Institute for Biological Standards and Control (Hertfordshire, UK) and diluted to concentrations of L1 (20 IU/mL), L2 (10 IU/mL), L3 (5 IU/mL), L4 (2.5 IU/mL), and L10 $(0 \mathrm{IU} / \mathrm{mL})$. Serum samples $(n=153)$ were collected from the General Hospital of Guangzhou Military Command of PLA. HIV antibody and p24 negative samples were confirmed by two different commercially available fourthgeneration HIV ELISA test reagents.

2.3. Gene Cloning and Recombinant Protein Expression. DNA sequence of the 149 354-amino acid sequence of HIV p55 Gag protein in the NCBI database (NP_057850.1) encoding the p24 gene was designed with codon optimization and synthesized by Shanghai Shenggong Co., Ltd. (Shanghai, China). The purified p24 PCR product and the pET28a(+) plasmid were both double digested with $\mathrm{NdeI}$ and XhoI restriction enzymes and ligated by T4 DNA ligase to construct pET28ap24 plasmid. E. coli BL21 (DE3) with recombinant plasmid were cultured in LB medium supplemented with $50 \mu \mathrm{g} / \mathrm{mL}$ kanamycin at $37^{\circ} \mathrm{C}$ until the logarithmic phase (at $\mathrm{OD}_{600}$ of $0.6 \sim 0.8$ ) before induction with final concentration of $1.0 \mathrm{mM}$ IPTG at $37^{\circ} \mathrm{C}, 25^{\circ} \mathrm{C}$, and $18^{\circ} \mathrm{C}$ to $\mathrm{OD}_{600}$ of 2.0 , respectively. Recombinant protein was purified on a HiTrap $\mathrm{Ni}^{2+}$ column using AKTAPurifier 100 (GE Healthcare Life Sciences, PA, USA).

2.4. Production of $m A b s$. Six-to-eight-week-old BALB/c mice were immunized subcutaneously with $100 \mu \mathrm{g}$ r-p24 mixed with the equal volume of Freund's complete adjuvant (SigmaAldrich, MN, USA). On the 14th and 28th day, mice were boosted with $50 \mu \mathrm{g}$ r-p24 mixed with the equal volume of Freund's incomplete adjuvant (Sigma-Aldrich, MN, USA). On day 38, a final injection of $50 \mu \mathrm{g}$ r-p24 in PBS was administered intraperitoneally. Hybridoma and mAbs were generated as described previously [9].

2.5. Antibody-Capture Indirect Sandwich ELISA. A novel antibody-capture indirect sandwich ELISA method was designed to screen the $\mathrm{mAb}$ pairs recognizing r-p24. ELISA microtiter plates were coated with different mAbs $(10 \mu \mathrm{g} / \mathrm{mL}$ in PBS, pH 9.6) and incubated overnight at $4^{\circ} \mathrm{C}$ followed by blocking with $3 \%$ BSA for $2 \mathrm{hr}$. For labeling of the detector antibody, $2 \mu \mathrm{g} / \mathrm{mL}$ of each $\mathrm{mAb}$ was dissolved in PBS dilution buffer (containing $0.05 \%(\mathrm{v} / \mathrm{v})$ Tween 20 and $1 \%(\mathrm{v} / \mathrm{v})$ BSA) and $0.1 \%(\mathrm{v} / \mathrm{v})$ HRP conjugated goat-anti-mouse antibody (GAM-HRP) for 30 minutes before use. About $75 \mu \mathrm{L}$ r-p24 $(1 \mu \mathrm{g}$ of protein/mL in PBS) containing $4 \%$ healthy mouse serum was incubated with $75 \mu \mathrm{L}$ detector $\mathrm{mAb}$ for $5 \mathrm{mins}$ reaction time after which $100 \mu \mathrm{L}$ of the mixture was then added to each well in duplicate and then rinsed after 30 mins. The subsequent peroxidase reaction step was performed and all assay results were read with a microplate reader Thermo Scientific MK3 (Thermo Fisher Scientific, MA, USA) at wavelengths $450 \mathrm{~nm}$.

2.6. Gold Immunochromatographic Assay for the Evaluation of p24 Protein. Monoclonal antibody pairs were used as capture and detector antibodies on the GICA platform. The detector antibody was labeled by conjugation to colloidal gold, mixed with active blocker against heterophilic antibodies and rheumatoid factor. The mixture was sprayed on glass fiber at $40 \mu \mathrm{L} / \mathrm{cm}^{2}$. The capture $\mathrm{mAb}$, goat-anti-mouse IgG, and active blocker were sprayed on a nitrocellulose membrane at a concentration of $2.0 \mathrm{mg} / \mathrm{mL}$ with a line thickness of $2 \mu \mathrm{L} / \mathrm{cm}$ to form the test, control, and block lines, respectively. Immunochromatographic test strips were made as described previously [10]. A maximum of $70 \mu \mathrm{L}$ sample was added to the sample application site and the color development was observed after 20 mins.

2.7. GICA Test Strip Sensitivity to Recombinant p24 Antigen. Serial dilutions of r-p24 (1000 pg/mL, $250 \mathrm{pg} / \mathrm{mL}, 100 \mathrm{pg} / \mathrm{mL}$, $50 \mathrm{pg} / \mathrm{mL}, 25 \mathrm{pg} / \mathrm{mL}, 10 \mathrm{pg} / \mathrm{mL}$, and $0 \mathrm{pg} / \mathrm{mL}$ ) were applied to the GICA test strips to check the sensitivity level at different antigen concentrations. Strips were observed for a maximum of 20 mins and the color development was compared with a standard color chart. The band intensity was then graded.

\section{Results}

3.1. Expression of Recombinant Protein. It was observed that higher incubation temperatures resulted in the formation of inclusion bodies while lower incubation temperatures showed high expression levels of soluble r-p24 proteins. The expression was carried out at $18^{\circ} \mathrm{C}$ and the r-p24 protein was purified on a HiTrap $\mathrm{Ni}^{2+}$ column with a total purity of $>95 \%$ (Figure 1(a), lane 7 ). The purified protein of interest was confirmed by ELISA analysis of the protein using commercially available monoclonal antibody against p24 antigen (Figure 1(b)).

3.2. Screening of $m A$ bs. 28 stable anti-r-p24 hybridoma clones were selected using indirect ELISA. Capture and detector $\mathrm{mAb}$ combinations were paired and selected from these 28 clones for reactivity against the immunogen through indirect sandwich ELISA. Of $784(28 \times 28)$ sandwich $\mathrm{mAb}$ combinations, 34 pairs could react with $\mathrm{r}-\mathrm{p} 24$ at $1 \mu \mathrm{g} / \mathrm{mL}$ and 13 of those showed strong sensitivity with the r-p24 protein. A total of $15 \mathrm{mAbs}$ pairs could react with $1 \mu \mathrm{g} / \mathrm{mL}$ r-p24 and only $2 \mathrm{mAbs}$ pairs could react with $1 \mathrm{ng} / \mathrm{mL} \mathrm{r}-\mathrm{p} 24$. An 


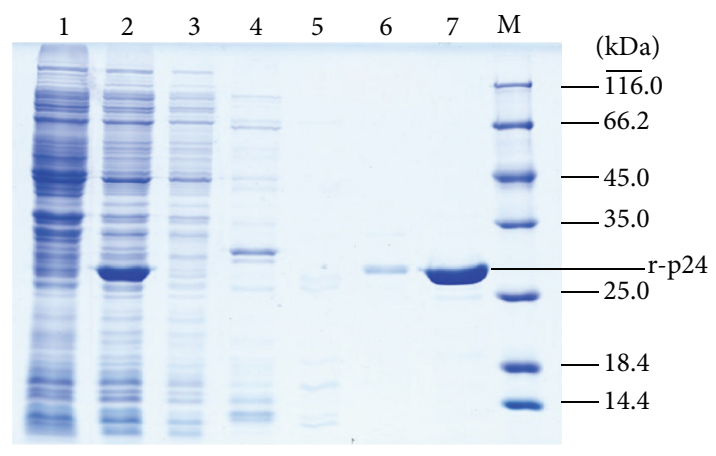

(a)

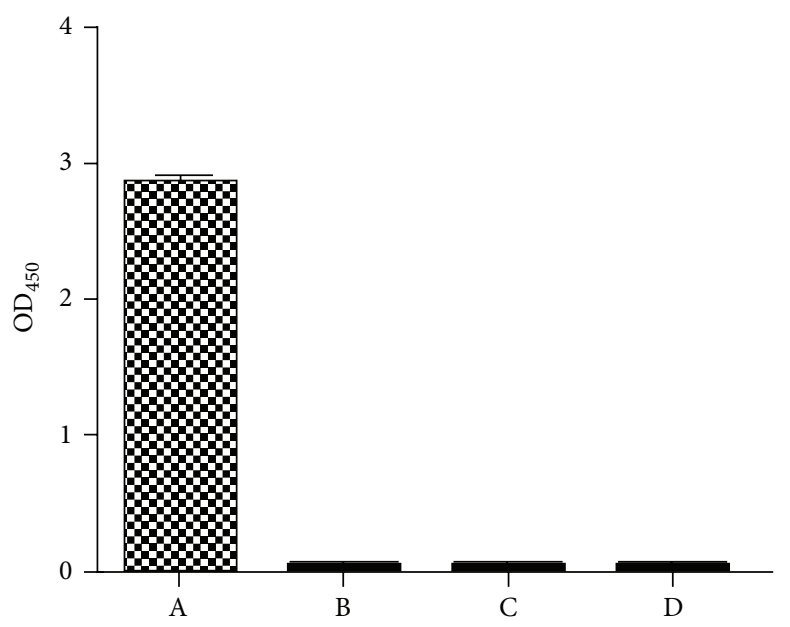

(b)

FIGURE 1: Preparation and identification of recombinant p24. (a) Expression and purification of recombinant p24. 1: whole cell lysate without IPTG induction, 2: whole cell lysate with IPTG induction, and 3: flow through solution; lanes 4 to 7 are four different solutions eluted by $50 \mathrm{mM}, 150 \mathrm{mM}, 300 \mathrm{mM}$, and $500 \mathrm{mM}$ imidazole buffer, respectively. (b) Indirect ELISA analysis of the recombinant p24. A: antip24 antibody as the primary antibody, B: blank without primary antibody, C: blank without coating antigen, and D: blank without primary antibody and coating antigen.

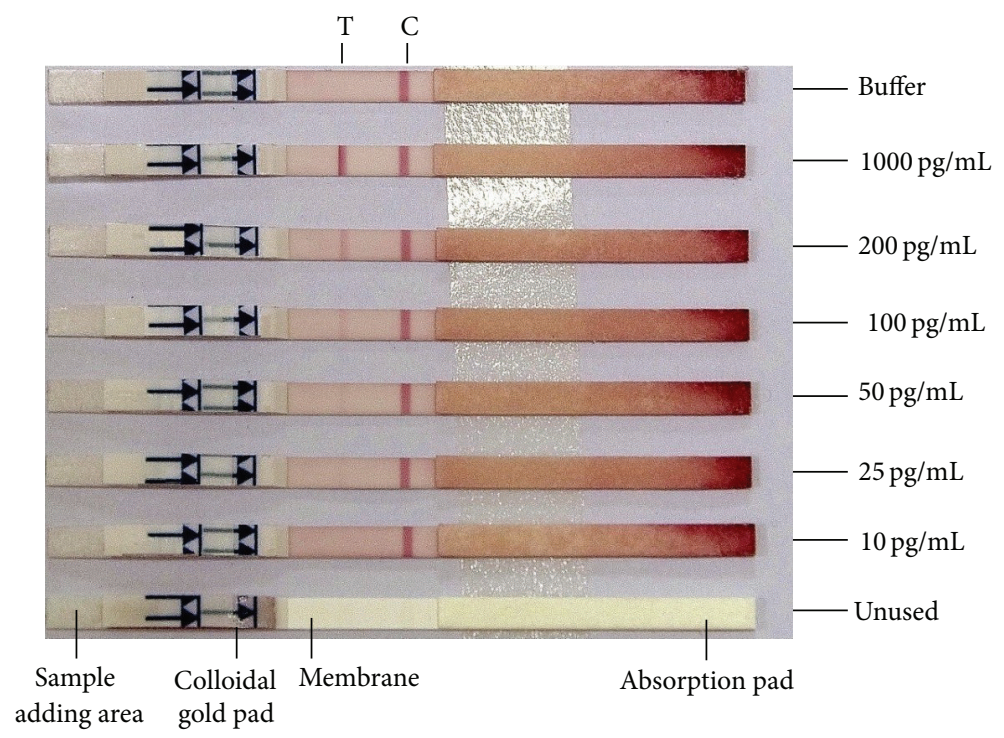

FIGURE 2: Sensitivity of GICA to r-p24 antigen. GICA test strips were treated with different concentrations $(1000 \mathrm{pg} / \mathrm{mL}, 200 \mathrm{pg} / \mathrm{mL}$, $100 \mathrm{pg} / \mathrm{mL}, 50 \mathrm{pg} / \mathrm{mL}, 25 \mathrm{pg} / \mathrm{mL}$, and $10 \mathrm{pg} / \mathrm{mL}$ ) of r-p24 antigen. T and C represent the test and control lines, respectively.

antibody pair consisting of capture (3-1D5) and detector (48 A10) showed a relatively higher sensitivity to p24 and were selected for later GICA tests.

3.3. Test Strip Sensitivity to Recombinant p24 Antigen. The sensitivity of the test strips using capture (3-1D5) and detector (4-8A10) was determined by treatment with different antigen concentrations $(1000 \mathrm{pg} / \mathrm{mL}, 200 \mathrm{pg} / \mathrm{mL}, 100 \mathrm{pg} / \mathrm{mL}$, $50 \mathrm{pg} / \mathrm{mL}, 25 \mathrm{pg} / \mathrm{mL}, 10 \mathrm{pg} / \mathrm{mL}$, and $0 \mathrm{pg} / \mathrm{mL}$ ) and the band intensity was evaluated after 20 mins by comparing with a standard color chart. Desired sensitivity for GICA was observed at $25 \mathrm{pg} / \mathrm{mL}$ of antigen (Figure 2).
3.4. GICA for HIV-1 p24 Positive and Negative Samples. GICA lateral strips made of 3-1D5 and 4-8A10 were used to detect HIV-1 p24 antigen positive serum samples from the National Reference (NR) of HIV and p24 negative serum samples (Table 1). P1 to P10 (p24 positive samples in the NR) were consequently detected by the GICA method. Of the p24 sensitivity samples in the NR (L1 to L10), the L1, L2, and L3 samples with higher concentrations of p24 protein were positively detected by GICA while the lower concentration samples (L4-L10) were negative. Compared with the fourthgeneration ELISA test reagent Vironostika HIV Uni-Form II Ag/Ab (Biomérieux, Boxtel, The Netherlands), three false 
TABLE 1: The detection results of National Reference for HIV-1 p24 antigen by GICA strips.

\begin{tabular}{lccc}
\hline Sample & Derivation of references & Genotype & Detection level \\
\hline P1 & P24 positive Sample 34\# & AE & Faint \\
P2 & P24 positive Sample 106\# & B & Faint \\
P3 & P24 positive Sample 116\# & B & Medium \\
P4 & P24 positive Sample 119\# & B & Weak \\
P5 & 500 fold-diluted laboratory-grown virus sample A & Not given & Medium \\
P6 & 100 fold-diluted laboratory-grown virus sample A & Not given & Weak \\
P7 & 1000 fold-diluted laboratory-grown virus sample L & B & Faint \\
P8 & 10000 fold-diluted laboratory-grown virus sample L & B & Faint \\
P9 & 50 fold-diluted HIV-1 window period Sample P & AE & Faint \\
P10 & WHO Standard p24 25 U/mL & B & Bedium \\
L1 & WHO Standard p24 20 U/mL & B & Medium \\
L2 & WHO Standard p24 $10 \mathrm{U} / \mathrm{mL}$ & B & Weak \\
L3 & WHO Standard p24 $5 \mathrm{U} / \mathrm{mL}$ & B & Faint \\
L4 & WHO Standard p24 $2.5 \mathrm{U} / \mathrm{mL}$ & B & Negative \\
L10 & Buffer for L Series & Negative \\
\hline
\end{tabular}

Detection level: Band intensity was read independently by two individuals.

positives were observed in the GICA test when p24 negative serum samples $(n=153)$ were tested, giving an overall specificity of $98.03 \%$.

\section{Discussion}

The number of new HIV infection cases has been on the increase despite numerous awareness programs and efforts to curtail the spread of infection. With the introduction of rapid HIV antibody test kits, HIV screening has become more decentralized with more tests done on an individual rather than batch [21]. Hence, there is an urgent need for simple, inexpensive, rapid, and accurate detection formats to shorten the window period of HIV testing and thereby reduce the risk of transmitting the virus from person to person during blood transfusion. GICA techniques have been applied in the third-generation HIV rapid detection reagents, but there are no commercialized available GICA rapid diagnostic reagents which can quickly detect HIV antibodies and HIV-1 p24 antigen in clinical samples. The development of rapid HIV testing reagents for p24 antigen detection could provide an easy detection method and would further enhance the sensitivity of currently available rapid test kits for early detection of HIV infection; hence, the production of HIV-1 p24 rapid GICA detection reagent is of great significance.

The GICA method described here could provide a much easier, rapid, and relatively inexpensive alternative to current ELISA protocols for p24 antigen detection. The LOD of $25 \mathrm{pg} / \mathrm{mL}$ for p24 is close to that observed in many commercially available antigen/antibody combination ELISAs. The GICA also demonstrated a good ability to detect low p24 concentrations in the National Reference of HIV-1 p24 antigen. This assay could detect all the $10 \mathrm{HIV}-1 \mathrm{p} 24$ positive serum samples including HIV-1 AE and B genotype samples. The sensitivity of the GICA was confirmed to be $5 \mathrm{IU} / \mathrm{mL}$ when WHO standard p24 sensitivity samples in the National Reference of HIV-1 p24 antigen were tested.
Chemiluminescent microparticle immunoassays and enzyme linked fluorescence assays have also been developed recently for commercial use, but these require complete packages of reagents and supports (Table 2). In the past decade, HIV-1 p24 antigen assays have significantly improved, as well as the introduction of new methodology such as nanoparticle-based biobarcode amplification assays, magnetic immunochromatography assays, and immunosensor assays (Table 2). It has also been reported that the ultrasensitive capacitive immunosensor assay can decrease the LOD of p24 antigen detection to about $7.9 \times 10^{-8} \mathrm{pg} / \mathrm{mL}$ (Table 2). However, these assays generally require complex instruments or well-trained technicians for their operation which ultimately limit their use in point-of-care testing, especially in remote areas of most developing countries.

In this research, a novel antibody-capture indirect sandwich ELISA method was used for the rapid screening of antibody pairs. The selected antibody pairs showed good performance when applied in both sandwich ELISA and GICA. A total of $28 \mathrm{mAbs}$ were obtained for combination experiments to screen the mAb pairs that could function well on GICA platform. Among these pairs, only one antibody pair showed the expected sensitivity for use on the GICA platform. Nevertheless, it is anticipated that more sensitive antibody pairs could be obtained by optimizing the immunization and antibody preparation process so as to enhance the sensitivity and specificity of the GICA kits. Most GICA mAb pairs perform well on the ELISA platform and some other immunological assays such as chemiluminescence microparticle immunoassay and fluorescence labeled immunochromatography. GICA strips can be applied in qualitative detection or semiquantitative detection of antigens. These results showed that the mAb pair can detect $20 \mathrm{pg} / \mathrm{mL}$ p24 antigen in ELISA method with HRP system (data not shown). In addition, fluorescent secondary antibody instead of colloidal gold can be used [22], and the consequent signal can be detected accurately by machine for p 24 quantification. 


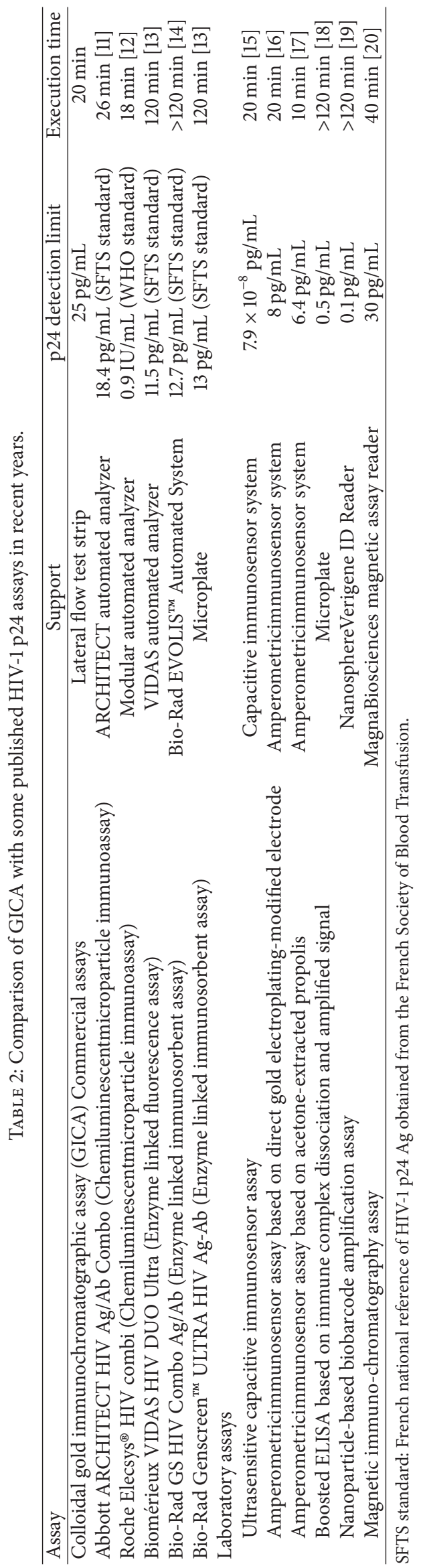


A rapid assay for the simultaneous detection of both p24 antigen and HIV specific antibody would provide a rapid diagnostic tool for screening HIV infected blood or serum specimen and may serve as a better substitute in commercially available fourth-generation ELISAs. Further researches could focus on improving the sensitivity and specificity of the GICA in detecting p24 antigen and HIV antibodies in a single device and thus accelerate their application in the fourth-generation HIV immunoassays.

\section{Conflict of Interests}

The authors declare that there is no conflict of interests regarding the publication of this paper.

\section{Acknowledgments}

This work was supported by the Science and Technology Planning Project of Guangdong Province (Grant no. 2012A080800007), the National Natural Science Foundation of China (Grant no. 21306055), Guangdong Natural Science Foundation (Grant no. 2014A030313261), and the Fundamental Research Funds for the Central Universities (Grant no. 2015ZM161).

\section{References}

[1] C. Momany, L. C. Kovari, A. J. Prongay et al., "Crystal structure of dimeric HIV-1 capsid protein,” Nature Structural Biology, vol. 3, no. 9, pp. 763-770, 1996.

[2] M. F. Summers, L. E. Henderson, M. R. Chance et al., "Nucleocapsid zinc fingers detected in retroviruses: EXAFS studies of intact viruses and the solution-state structure of the nucleocapsid protein from HIV-1," Protein Science, vol. 1, no. 5, pp. 563-574, 1992.

[3] E. W. Fiebig, D. J. Wright, B. D. Rawal et al., "Dynamics of HIV viremia and antibody seroconversion in plasma donors: implications for diagnosis and staging of primary HIV infection," AIDS, vol. 17, no. 13, pp. 1871-1879, 2003.

[4] L. R. Petersen, G. A. Satten, R. Dodd et al., "Duration of time from onset of human immunodeficiency virus type 1 infectiousness to development of detectable antibody," Transfusion, vol. 34, no. 4, pp. 283-289, 1994.

[5] M. Miedouge, M. Grèze, A. Bailly, and J. Izopet, "Analytical sensitivity of four HIV combined antigen/antibody assays using the p24 WHO standard," Journal of Clinical Virology, vol. 50, no. 1, pp. 57-60, 2011.

[6] L.-R. Lin, Z.-G. Fu, B. Dan et al., "Development of a colloidal gold-immunochromatography assay to detect immunoglobulin G antibodies to Treponema pallidum with TPN17 and TPN47," Diagnostic Microbiology and Infectious Disease, vol. 68, no. 3, pp. 193-200, 2010.

[7] L. R. da Motta, A. C. Vanni, S. K. Kato et al., "Evaluation of five simple rapid HIV assays for potential use in the Brazilian national HIV testing algorithm," Journal of Virological Methods, vol. 194, no. 1-2, pp. 132-137, 2013.

[8] G. P. Zhang, X. N. Wang, J. F. Yang et al., "Development of an immunochromatographic lateral flow test strip for detection of $\beta$-adrenergic agonist Clenbuterol residues," Journal of Immunological Methods, vol. 312, no. 1-2, pp. 27-33, 2006.
[9] E. E. Dzakah, K. Kang, C. Ni et al., "Plasmodium vivax aldolasespecific monoclonal antibodies and its application in clinical diagnosis of malaria infections in China," Malaria Journal, vol. 12, no. 1, pp. 199-206, 2013.

[10] A. Fatima, H. Wang, K. Kang et al., "Development of VHH antibodies against dengue virus type 2 NS1 and comparison with monoclonal antibodies for use in immunological diagnosis," PLoS ONE, vol. 9, no. 4, Article ID e95263, 2014.

[11] C. A. Brennan, J. Yamaguchi, A. Vallari, P. Swanson, and J. R. Hackett, "ARCHITECT ${ }^{\circledR}$ HIV Ag/Ab Combo assay: correlation of HIV-1 p24 antigen sensitivity and RNA viral load using genetically diverse virus isolates," Journal of Clinical Virology, vol. 57, no. 2, pp. 169-172, 2013.

[12] C. M. Tao, Y. Cho, K. P. Ng et al., "Validation of the Elecsys ${ }^{\circledR}$ HIV combi PT assay for screening and reliable early detection of HIV-1 infection in Asia," Journal of Clinical Virology, vol. 58, no. 1, pp. 221-226, 2013.

[13] T. D. Ly, A. Ebel, V. Faucher, V. Fihman, and S. Laperche, "Could the new HIV combined p24 antigen and antibody assays replace p24 antigen specific assays?" Journal of Virological Methods, vol. 143, no. 1, pp. 86-94, 2007.

[14] E. O. Mitchell, G. Stewart, O. Bajzik, M. Ferret, C. Bentsen, and M. K. Shriver, "Performance comparison of the 4th generation Bio-Rad Laboratories GS HIV Combo Ag/Ab EIA on the EVOLIS $^{\mathrm{TM}}$ automated system versus Abbott ARCHITECT HIV $\mathrm{Ag} / \mathrm{Ab}$ Combo, Ortho Anti-HIV $1+2$ EIA on Vitros ECi and Siemens HIV-1/O/2 enhanced on Advia Centaur," Journal of Clinical Virology, vol. 58, supplement 1, pp. e79-e84, 2013.

[15] K. Teeparuksapun, M. Hedström, E. Y. Wong, S. Tang, I. K. Hewlett, and B. Mattiasson, "Ultrasensitive detection of HIV1 p24 antigen using nanofunctionalized surfaces in a capacitive immunosensor," Analytical Chemistry, vol. 82, no. 20, pp. 84068411, 2010.

[16] L. Zheng, L. Jia, B. Li et al., "A sandwich HIV p24 amperometric immunosensor based on a direct gold electroplating-modified electrode," Molecules, vol. 17, no. 5, pp. 5988-6000, 2012.

[17] F. Kheiri, R. E. Sabzi, E. Jannatdoust, E. Shojaeefar, and H. Sedghi, "A novel amperometric immunosensor based on acetone-extracted propolis for the detection of the HIV-1 p24 antigen," Biosensors and Bioelectronics, vol. 26, no. 11, pp. 44574463, 2011.

[18] R. Sutthent, N. Gaudart, K. Chokpaibulkit, N. Tanliang, C. Kanoksinsombath, and P. Chaisilwatana, "p24 antigen detection assay modified with a booster step for diagnosis and monitoring of human immunodeficiency virus type 1 infection," Journal of Clinical Microbiology, vol. 41, no. 3, pp. 1016-1022, 2003.

[19] S. Tang, J. Zhao, J. J. Storhoff et al., "Nanoparticle-based biobarcode amplification assay (BCA) for sensitive and early detection of human immunodeficiency type 1 capsid (p24) antigen," Journal of Acquired Immune Deficiency Syndromes, vol. 46, no. 2, pp. 231-237, 2007.

[20] S. Workman, S. K. Wells, C.-P. Pau et al., "Rapid detection of HIV-1 p24 antigen using magnetic immuno-chromatography (MICT)," Journal of Virological Methods, vol. 160, no. 1-2, pp. 1421, 2009.

[21] T. C. Granade, "Use of rapid HIV antibody testing for controlling the HIV pandemic," Expert Review of Anti-infective Therapy, vol. 3, no. 6, pp. 957-969, 2005.

[22] Z. Bai, Y. Luo, W. Xu et al., "Development of a new fluorescence immunochromatography strip for detection of chloramphenicol residues in chicken muscles," Journal of the Science of Food and Agriculture, vol. 93, no. 15, pp. 3743-3747, 2013. 

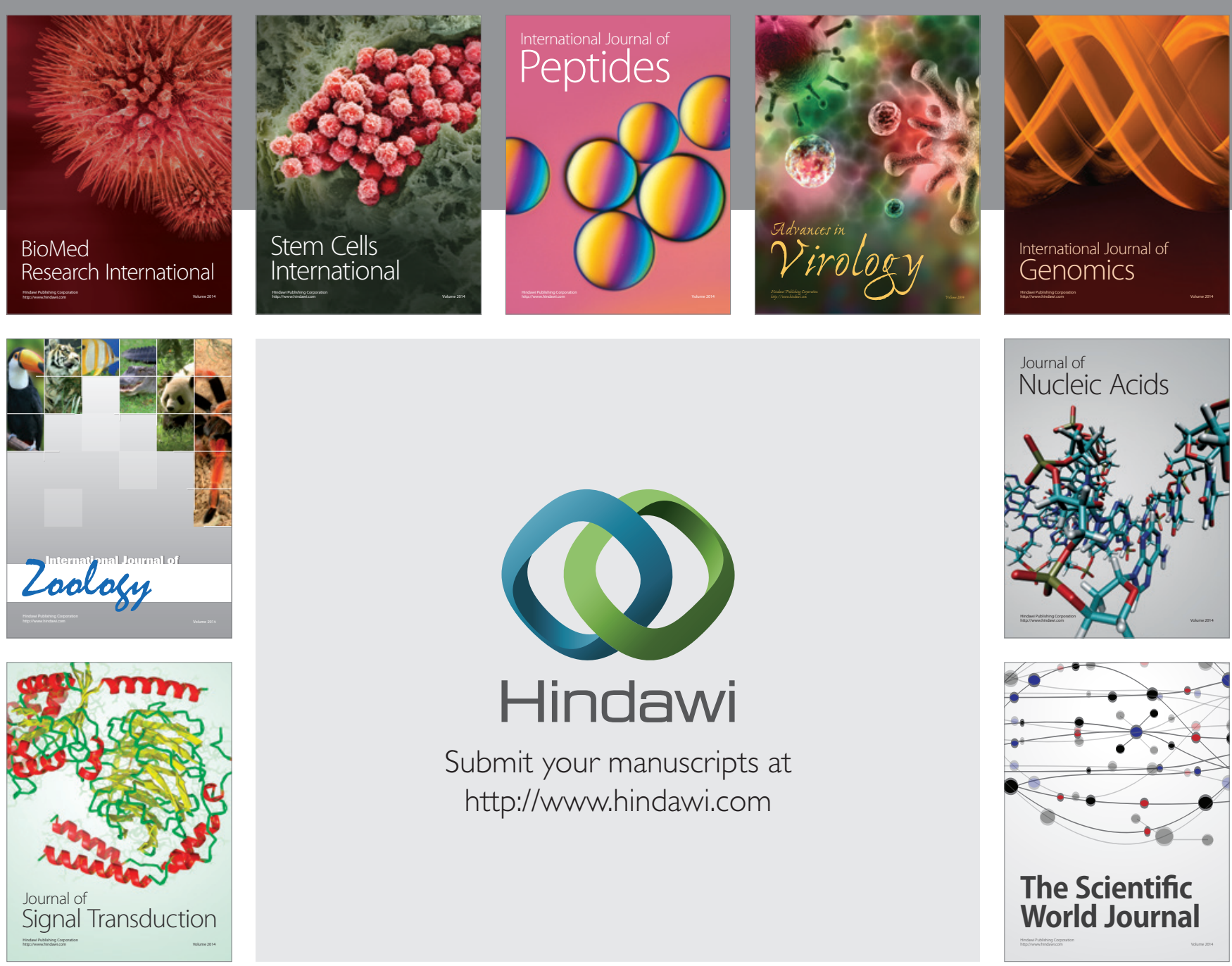

Submit your manuscripts at

http://www.hindawi.com
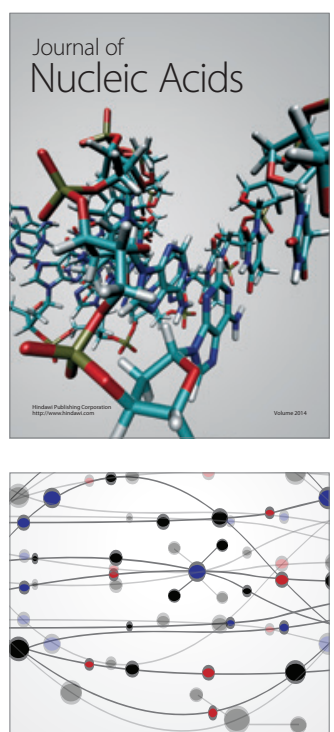

The Scientific World Journal
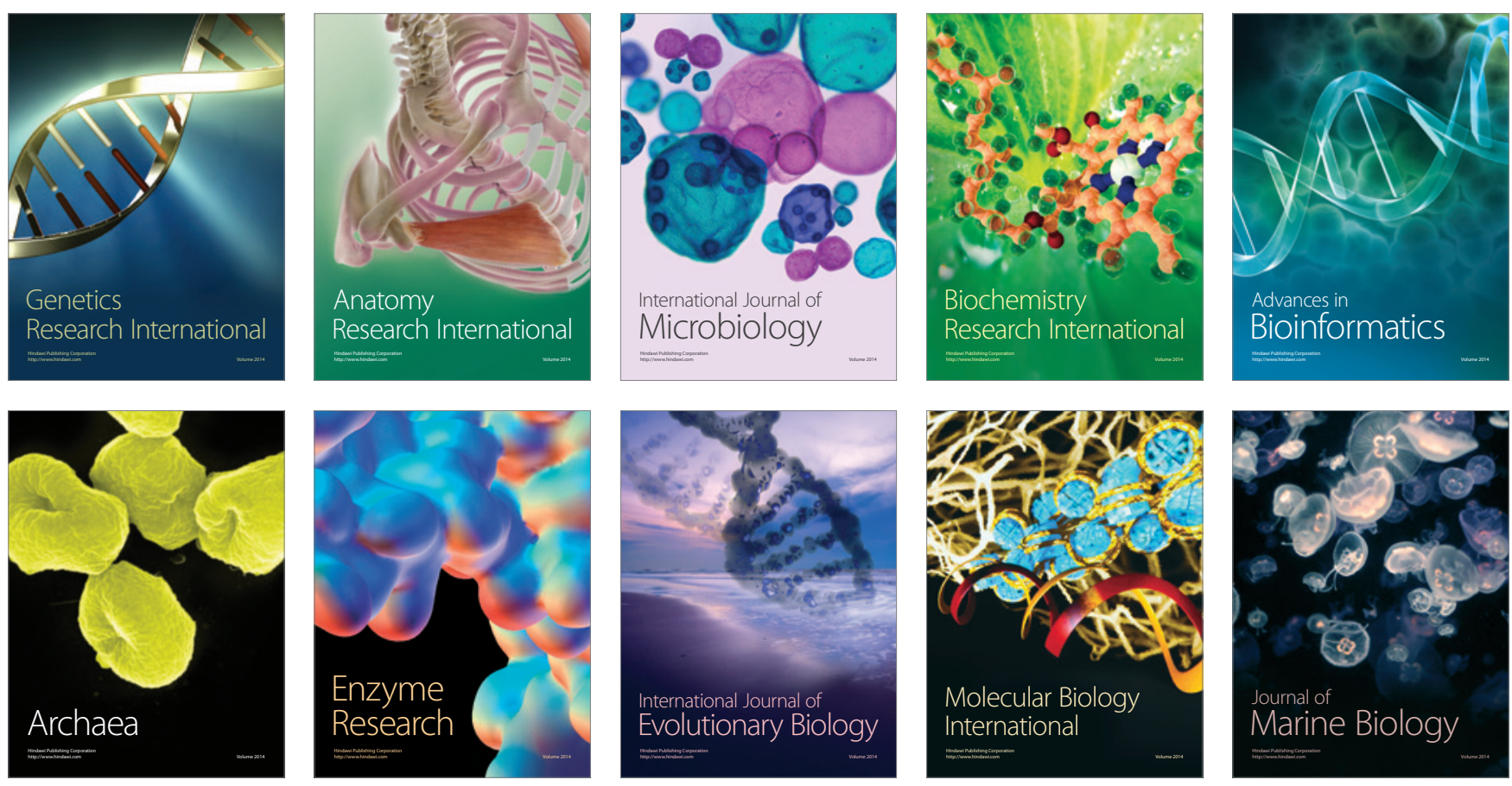